Volume 5, No. 2, Bulan Desember Tahun 2021, pp. 589-602

ISSN 2549-1164 (online)

DOI : $10.36526 /$ tr.v\% vi\% i.1462

Available online at https:/ / ejournal.unibabwi.ac.id/ index.php/ transformasi

\title{
ANALISIS KESULITAN DAN PEMBERIAN SCAFFOLDING DALAM PEMBELAJARAN DISCOVERY LEARNING
}

\author{
Eric Dwi Putra ${ }^{1}$, Lutfiyah ${ }^{2}$, Sri Retno Anggraini ${ }^{3}$ \\ 1,2,3FKIP, UNIVERSITAS PGRI ARGOPURO JEMBER \\ email korespondensi : dwieric454@gmail.com
}

Diterima : (03-09-2021), Revisi: (02-12-2021), Diterbitkan : (05-12-2021)

\begin{abstract}
ABSTRAK
Tujuan penelitian ini adalah untuk mendeskripsikan kesulitan siswa dalam menyelesaikan masalah matematika dalam pembelajaran Discovery Learning serta pemberian scaffolding untuk mengatasi kesulitan. Data diperoleh menggunakan instrument tes dan lembar wawancara. Penelitian ini merupakan penelitian deskriptif dengan pendekatan kualitatif. Sumber data siswa kelas X SMK Islam Bustanul Ulum Pakusari sebanyak 24 siswa. Hasil penelitian menunjukkan bahwa kesulitan yang dialami saat menyelesaikan soal program linier antara lain: (1) menentukan kondisi awal, (2) menentukan sistem persamaan linier, (3) proses penyelesaian sistem persamaan linier, (4) proses penerjemahan jawaban, (5) pengecekan jawaban. Adapun bentuk pemberian scaffolding yang tepat untuk mengatasi beberapa kesulitan diantaranya: (1) explaining dengan penjelasan penentuan variabel sebelum membuat sistem persamaan sangat penting, (2) reviewing dengan meminta membaca ulang soal untuk mendapatkan informasi yang diketahui dan ditanya, (3) restructuring dengan memberikan contoh pengerjaan, (4) meminta kelompok untuk melihat kembali proses eliminasi yang telah dilakukan, (5) making connection dengan meminta membuat hubungan yang diketahui dengan pemisalan variabel, serta (6) meminta menghubungkan yang ditanyakan dengan hasil.
\end{abstract}

Kata kunci: kesulitan siswa, Discovery Learning, Scaffolding. 


\begin{abstract}
The purpose of this research was to describe the difficulties in solving mathematical problems in Discovery Learning and providing scaffolding to overcome difficulties. Data were obtained using test instruments and interview sheets. This research is a descriptive research with a qualitative approach. The data sources for class X Islamic Vocational School Bustanul Ulum Pakusari were 24 students. The results showed that the difficulties experienced when solving linear programming problems were: (1) determining the initial conditions, (2) determining a system of linear equations, (3) the process of solving a system of linear equations, (4) translating answers, (5) checking the answer. The form of providing the right scaffolding to overcome several difficulties include: (1) explaining the determination of variables before making a system of equations is very important, (2) reviewing by asking to reread the questions to get information that is known and asked, (3) restructuring by giving examples of work, (4) asking the group to review the elimination process that has been carried out, (5) making a connection by asking to make a known relationship with the example of a variable (6) asking to connect the question asked with the results.
\end{abstract}

Keywords: student difficulties, Discovery Learning, Scaffolding

\title{
Pendahuluan
}

Pelajaran matematika perlu diberikan kepada siswa sejak sekolah dasar untuk memberi bekal dengan kemampuan berpikir logis, kritis, sistematis, analitis, kreatif, maupun kemampuan bekerjasama (Kamarullah, 2017). Pada pembelajaran matematika masih banyak materi yang kurang efektif sehingga siswa kurang memahami materi dan mengalami kesulitan dalam menyelesaikan soal-soal matematika. Amalia \& Putra (2019) menyatakan bahwa pendidik seharusnya dapat mendesain pembelajaran yang mampu membuat siswa meningkatkan kemampuan berpikir kritis. Fakta di lapangan menunjukkan bahwa siswa masih kesulitan dan ada yang mengalami kegagalan dalam menyelesaikan soal-soal matematika. Zaqiyah, Lutfiyah, \& Sulisawati, (2020)menyebutkan bahwa saat ini masih banyak siswa mengalami kesulitan untuk mempelajari serta memahami materi matematika. Oleh karena itu guru harus dapat meningkatkan kualitas pembelajaran.

Upaya untuk meningkatkan kualitas pembelajaran di kelas pada dasarnya telah banyak dilakukan, salah satunya adalah menerapkan diskusi kelompok. Menurut Jatisunda, Suciawati, \& Nahdi, (2020) pertumbuhan konsep matematika berkembang dalam pikiran manusia ketika bersosialisasi atau berdiskusi. Diskusi kelompok adalah bentuk diskusi yang melibatkan kelompok kecil siswa yang berkisar antara 3 sampai 6 peserta untuk mencari solusi terhadap masalah yang dibe- 
rikan (Yaumi, 2018). Diskusi kelompok adalah salah satu bentuk kegiatan yang terdapat pada model pembelajaran discovery learning.

Menurut Alex \& Olubusuyi (In’am \& Hajar, 2017) penelitian pembelajaran yang berkaitan dengan discovery learning telah menunjukkan bahwa siswa memiliki kemampuan yang tinggi untuk mengikuti dengan sangat baik, sedangkan kelompok kemampuan yang kurang dapat meningkatkan kemampuan itu sendiri. Model pembelajaran discovery mengajarkan kepada siswa untuk memahami konsep sehingga siswa tidak hanya menghafal banyak rumus. Carin dan Sund (Putra \& Amalia, 2020) menyatakan bahwa discovery merupakan suatu proses mental di mana individu mengasimilasi konsep-konsep serta prinsip-prinsip.

Bruner menjelaskan bahwa discovery learning merupakan model pembelajaran yang menggunakan konstruktivis berbasis inkuiri teori belajar yang terjadi dalam situasi pemecahan masalah di mana siswa belajar melalui pengetahuan yang ada dan pengalaman sebelumnya untuk menemukan fakta dan hubungan dengan materi baru yang dipelajari (Simamora, Saragih, \& Hasratuddin, 2018). Menurut Prince (Ramdhani, Usodo, \& Subanti, 2017) dengan mencari tahu sendiri dan menyelidiki, hasil yang diperoleh akan bertahan lama dalam ingatan dan tidak mudah dilupakan oleh siswa. Jika siswa terlibat aktif dalam menemukan prinsip dasar mereka sendiri, maka siswa akan memahami konsep dengan lebih baik, mengingat lebih lama dan dapat menggunakannya dalam konteks lain.

Discovery Learning terjadi ketika siswa harus menemukan pengetahuan secara mandiri dengan bahan yang disediakan. Jika siswa menemukan kesulitan dalam menjalankan tahap-tahap discovery learning maka siswa dapat menganalisis kembali masalah-masalah yang telah diidentifikasi sehingga dapat menentukan langkah yang seharusnya dilakukan agar kesulitan-kesulitan tersebut dapat diatasi (Haeruman, Rahayu, \& Ambarwati, 2017). Gooding (Santoso, Nusantara, \& Subanji, 2013) menyatakan bahwa kesulitan siswa dalam menyelesaikan soal cerita di antaranya adalah membaca dan memahami, membaca semua informasi, informasi yang mengganggu perhatian, membayangkan konteks, menulis kalimat matematika, penghitungan, dan menerjemahkan jawaban. Dalam pembelajaran discovery leaning, siswa juga banyak yang mengalami kesulitan dalam penyelesaian soal. Faktor penyebab dari kesulitan tersebut tidak hanya ada pada diri siswa, tetapi dapat juga disebabkan oleh faktor guru seperti kurangnya pengetahuan yang dimi- 
liki guru tentang topik yang diajarkan atau ketidaktepatan model/ metode pembelajaran yang diterapkan (Mustaqim, 2013).

Banyak upaya untuk mengatasi kesulitan siswa dalam menyelesaikan masalah matematika seperti scaffolding, pengajaran remedial, dan sebagainya. Scaffolding merupakan solusi yang efektif untuk menyelesaikan permasalahan kesulitan siswa dalam menyelesaikan masalah tentang matematika. Hal ini disebabkan beberapa alasan yaitu kesulitan yang dialami siswa dimungkinkan tidak pada semua langkah penyelesaian serta scaffolding dapat diberikan berdasarkan letak kesulitan dan kemampuan siswanya (Mustaqim, 2013).

Secara umum terdapat tiga pola pemberian scaffolding yaitu : (1) dimulai dari hal kongkrit atau hal sederhana terlebih dahulu; (2) pertanyaan bersifat refleksif dan memberikan pengertian konsep yang berhubungan dengan langkah-langkah penyelesaian untuk membimbing menemukan jawaban; (3) memberikan penekanan hubungan yang terdapat dalam melakukan langkah-langkah penyelesaian (Larasati \& Mampouw, 2018). Anghileri (Khatimah, Sa'dijah, \& Susanto, 2017) menjelaskan terdapat tiga tingkatan scaffolding, yaitu: (1) environmental provisions, yaitu penataan lingkungan belajar yang memungkinkan berlangsung tanpa intervensi langsung dari guru; (2) explaining, reviewing, and restructuring (penjelasan, peninjauan, dan restrukturisasi); dan (3) developing conceptual thinking (membangun pemikiran konseptual). Dalam penelitian ini, scaffolding yang diberikan berupa dukungan kepada siswa untuk belajar dan menyelesaikan masalah yang berupa petunjuk, pengingat, dorongan, menyederhanakan masalah, memberi contoh disaat menyelesaikan soal.

Suwanti (2016) menyatakan bahwa dengan pemberian scaffolding pada bagian sulit yang ditemui siswa dapat mengurangi dan menghilangkan kesulitan. Hasil penelitian Sari, Subanji, \& Hidayanto (2016) menunjukkan bahwa pemberian scaffolding dapat mengatasi kesulitan penalaran matematis yang dialami siswa dalam menyelesaikan masalah pada materi pola bilangan. Adapun kesulitan tersebut adalah : (1) menentukan pola serta struktur dalam mendeteksi keteraturan; (2) merumuskan generalisasi dugaan tentang keteraturan dari yang diobservasi; (3) melakukan evaluasi dugaan; serta (4) membangun maupun melakukan evaluasi argumen matematika. Berdasarkan uraian sebelumnya, maka penelitian ini difokuskan untuk mendeskripsikan kesulitan siswa dalam menyelesaikan masalah matematika dalam pembelajaran discovery learning dengan pemberian scaffolding. 


\section{Metode Penelitian}

Jenis penelitian yang digunakan adalah deskriptif dengan pendekatan kualitatif. Sumber data adalah siswa kelas X SMK Islam Bustanul Ulum Pakusari sebanyak 24 siswa. Selanjutnya sumber data dibagi menjadi 3 kelompok (K1, K2, K3) yang masing-masing kelompok terdiri dari 8 siswa. Ketiga kelompok siswa diberi tes untuk memperoleh data kesulitan siswa dalam menyelesaikan soal cerita materi Program Linear. Instrumen penelitian adalah peneliti sendiri, tes, serta lembar wawancara. Tes dilakukan sebanyak dua kali yaitu uji pendahuluan (untuk menentukan subjek penelitian dan mengetahui kesulitan siswa) dan tes kedua setelah diberikan scaffolding. Wawancara dilakukan secara semi terstruktur untuk menggali informasi kesulitan siswa serta pemberian bantuan sesuai dengan kesulitan yang dialami siswa. Wawancara dilakukan selama pemberian scaffolding. Analisis data dilakukan berdasarkan Miles, dkk (Santoso et al., 2013) yang memuat reduksi data, penyajian data, dan penarikan kesimpulan atau verifikasi.

\section{Hasil dan Pembahasan}

Pada tahap pendahuluan dilakukan pembagian siswa menjadi 3 kelompok. Pembagian kelompok didasarkan pada hasil uji pendahuluan. Selain itu juga dilakukan wawancara dengan guru pengajar untuk mengetahui kemampuan siswa. Pada perencanaan dilakukan penyusunan rencana pembelajaran, soal tes awal dan pemberian tes awal untuk mengetahui kesulitan yang dialami siswa.

Pada tahap tindakan diberikan materi dengan pembelajaran discovery learning dan mengetahui kesulitan siswa saat proses pembelajaran untuk diberikan scaffolding.

\section{Diagnosis Kesulitan Kelompok 1 (K1) dan Upaya Membantunya}

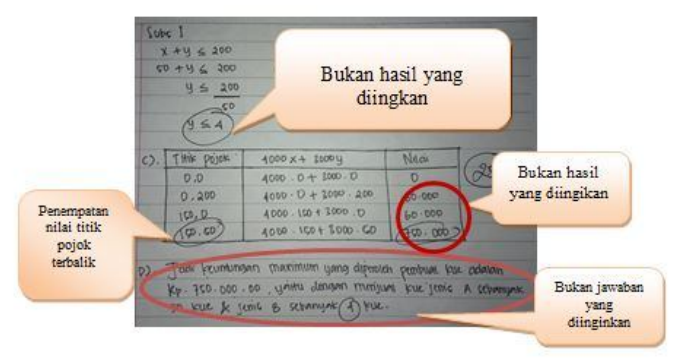

Gambar 1. Jawaban Siswa K1

Berdasarkan hasil pada gambar 1, terlihat bahwa K1 hanya berfokus pada perhi- 
tungan saja. Kesalahan terdapat dalam proses penentuan titik potong grafik dengan sumbu $y$ pada pertidaksamaan $x+y \leq 200$, subtitusi nilai $x$ dan $y$ yang sebelumnya bukan hasil yang diinginkan sehingga subtitusi pada fungsi tujuan tidak mendapat nilai yang seharusnya. K1 juga melakukan kesalahan dalam membuat kesimpulan karena kesalahan pada perhitungan sebelumnya.

Setelah K1 menyelesaikan soal yang diberikan, selanjutnya dilakukan wawancara tentang jawaban yang telah diberikan. Pada proses wawancara ditanyakan prosedur atau tahapan dalam menyelesaikan soal cerita yang diketahui sejak Sekolah Dasar hingga saat ini.

Berdasarkan hasil tes dan wawancara dapat diketahui bahwa K1 mengalami kesulitan dalam menentukan kondisi awal yaitu menuliskan apa yang diketahui, apa yang ditanya, serta proses perhitungan. Kesulitan juga dialami dalam menyimpulkan jawaban. Hal ini diketahui dari jawaban K1 yang berhenti pada proses perhitungan. Untuk itu perlu diberikan scaffolding berupa mencermati kembali soal, menuliskan apa yang diketahui, ditanya, dan menentukan variabel yang akan digunakan.

\section{Pemberian Scaffolding untuk Mengatasi Kesulitan K1 saat Penyelesaian Soal Materi Program Linier}

Berikut disajikan deskripsi pemberian scaffolding pada K1.

Tabel 1. Identifikasi Jenis Kesulitan Siswa serta Pemberian Scaffolding untuk K1

\begin{tabular}{|c|c|c|}
\hline Jenis kesulitan & $\begin{array}{c}\text { Kesalahan yang } \\
\text { terjadi }\end{array}$ & Bentuk Scaffolding yang Diberikan \\
\hline $\begin{array}{l}\text { Menentukan kon- } \\
\text { disi awal (menulis } \\
\text { apa yang diketahui } \\
\text { dan ditanyakan) }\end{array}$ & $\begin{array}{l}\text { Tidak mencermati } \\
\text { soal hanya berfokus } \\
\text { pada perhitungan } \\
\text { saja }\end{array}$ & $\begin{array}{l}\text { - } \\
\text { - } \quad \text { Revplaining } \\
\text { untuk mendapatkan informasi mengenai apa } \\
\text { yang diketahui dan yang ditanyakan soal. } \\
\text { - } \quad \text { Restructuring }\end{array}$ \\
\hline $\begin{array}{l}\text { Model matematika } \\
\text { (menentukan va- } \\
\text { riabel serta model } \\
\text { matematika) }\end{array}$ & $\begin{array}{l}\text { Tidak mendefinisi- } \\
\text { kan variabel terlebih } \\
\text { dahulu, salah dalam } \\
\text { menentukan varia- } \\
\text { bel }\end{array}$ & $\begin{array}{l}\text { - Explaining: menjelaskan pentingnya menentu- } \\
\text { kan variabel sebelum membuat sistem persa- } \\
\text { maan } \\
\text { - } \text { Reviewing: meminta subjek membaca ulang soal } \\
\text { untuk medapatkan informasi } \\
\text { - Restructuring: melakukan tanya jawab "biasanya } \\
\text { dalam menentukan variabel itu dengan cara } \\
\text { memisalkan, nah kalau soalnya seperti ini apa } \\
\text { yang kamu misalkan?" }\end{array}$ \\
\hline
\end{tabular}




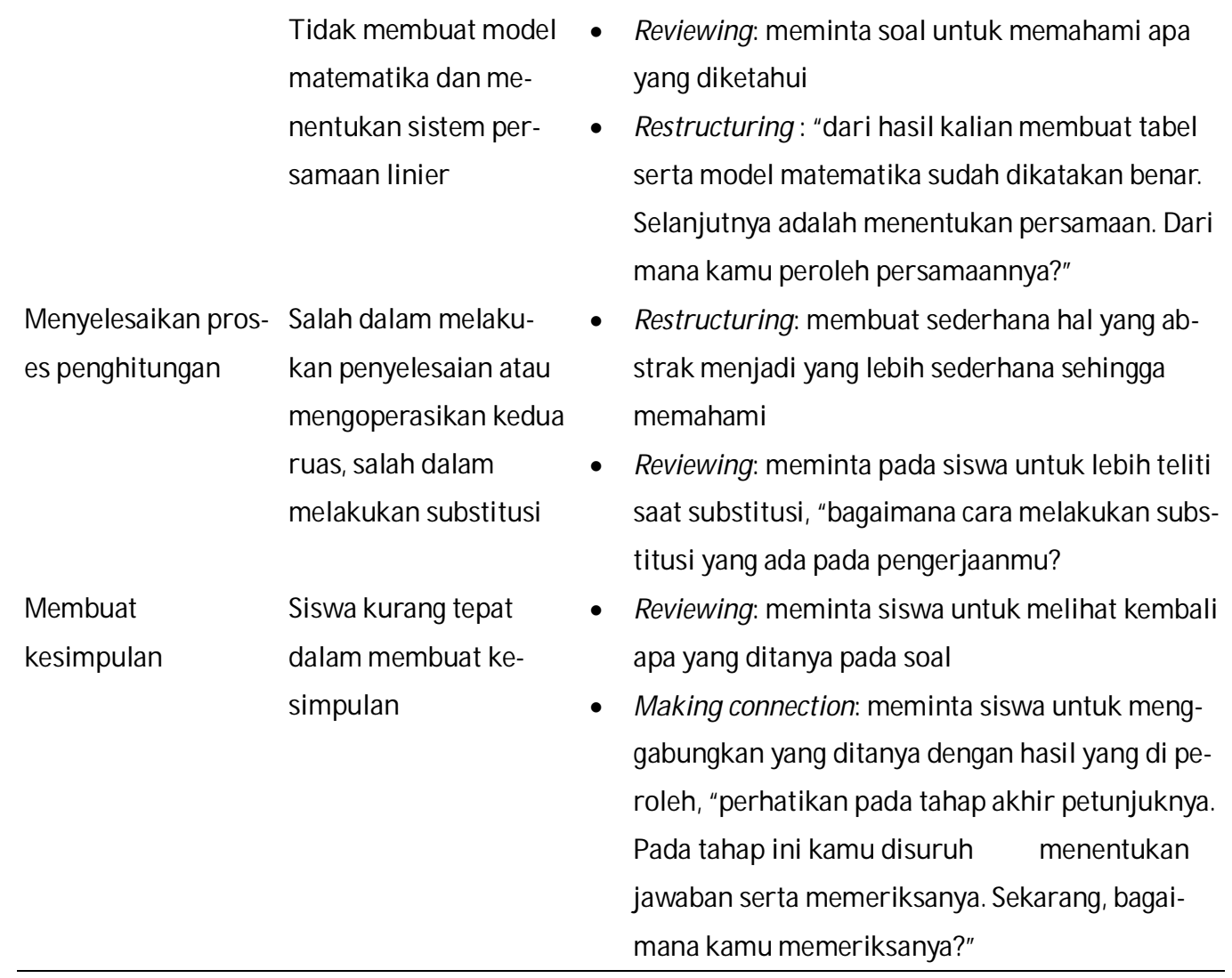

\section{Diagnosis kesulitan Kelompok 2 (K2) dan Upaya Membantunya}

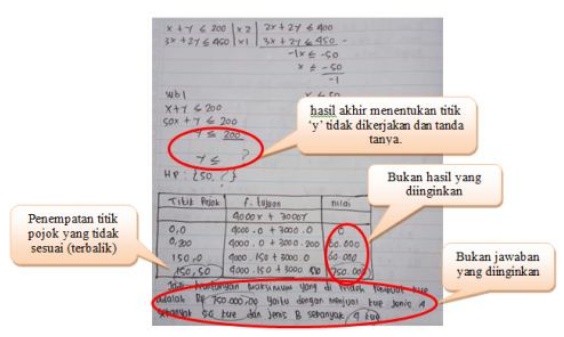

Gambar 2. Jawaban Siswa K2

Kesalahan yang dilakukan K2 diantaranya adalah tidak menentukan kondisi awal, tidak melanjutkan proses penentuan titik pojok y sehingga hasil akhir tidak diperoleh, serta tidak membuat kesimpulan akhir dari jawabannya. Hasil wawancara setelah pengerjaan soal menunjukkan bahwa K2 mengalami kesulitan pada saat mengerjakan soal. K2 menyatakan bahwa terdapat langkah-langkah pengerjaan soal cerita tetapi tidak ditulis dengan alasan jika ditulis akan lama dan membutuhkan banyak waktu. 
Berdasarkan hasil tes dan wawancara dapat diketahui bahwa K2 mengalami kesulitan dalam menentukan kondisi awal dan kondisi akhir, tidak teliti, serta kesulitan dalam pengelolaan waktu. Untuk itu perlu diberikan scaffolding berupa bimbingan penentuan kondisi awal dan penentuan kesimpulan akhir, serta pengerjaan soal.

\section{Pemberian Scaffolding untuk Mengatasi Kesulitan K2 saat Penyelesaian Soal Materi Program Linier}

Berikut disajikan deskripsi pemberian scaffolding pada K2.

Tabel 2. Identifikasi Jenis Kesulitan Siswa serta Pemberian Scaffolding untuk K2

\begin{tabular}{|c|c|c|}
\hline $\tan$ & $\begin{array}{c}\text { Kesalahan yang } \\
\text { terjadi }\end{array}$ & Bentuk Scaffolding yang Diberikan \\
\hline $\begin{array}{l}\text { Menentukan kondisi } \\
\text { awal (menulis apa } \\
\text { yang diketahui dan } \\
\text { ditanyakan) }\end{array}$ & $\begin{array}{l}\text { Salah dalam menulis } \\
\text { apa yang diketahui dan } \\
\text { tidak menulis apa yang } \\
\text { ditanyakan }\end{array}$ & $\begin{array}{l}\text { - Explaining: meminta siswa fokus memperhatikan } \\
\text { yang soal dengan membacakan soal berulang dan } \\
\text { memberi penekanan intonasi pada informasi } \\
\text { yang penting } \\
\text { - } \text { Reviewing: meminta membaca ulang soal untuk } \\
\text { mendapatkan informasi } \\
\text { - } \text { Restructuring: melakukan tanya jawab }\end{array}$ \\
\hline $\begin{array}{l}\text { Membuat model } \\
\text { matematika dan } \\
\text { menentukan sistem } \\
\text { persamaan linier }\end{array}$ & $\begin{array}{l}\text { - Salah membuat } \\
\text { model matematika, } \\
\text { belum mampu me- } \\
\text { nuliskan variabel } \\
\text { yang tepat } \\
\text { - Belum dapat me- } \\
\text { nentukan sistem } \\
\text { persamaan linier } \\
\text { dan cara menyele- } \\
\text { saikan } \\
\text { - Salah dalam me- } \\
\text { nentukan nilai y, } \\
\text { salah dalam proses } \\
\text { substitusi }\end{array}$ & $\begin{array}{l}\text { - } \quad \text { Reviewing: meminta siswa membaca apa yang } \\
\text { telah diketahui } \\
\text { - } \quad \text { Restructuring: menyederhanakan pertanyaan } \\
\text { soal, “Ok, jadi kamu mempunyai } 2 \text { yang diketahui, } \\
\text { yaitu barang kue jenis A dan Kue jenis B. Seka- } \\
\text { rang kamu terjemahkan apa yang diketahui men- } \\
\text { jadi persamaan berdasarkan variabel yang sudah } \\
\text { kamu tentukan sesuai tabel dan model matema- } \\
\text { tika serta fungsi tujuan yang sudah dibuat.” } \\
\text { - Explaining: menjelaskan metode yang diguna- } \\
\text { kan. } \\
\text { Reviewing: meminta kepada kelompok untuk me- } \\
\text { lihat kembali proses eliminasi }\end{array}$ \\
\hline $\begin{array}{l}\text { Kondisi akhir/ Ke- } \\
\text { simpulan }\end{array}$ & $\begin{array}{l}\text { Salah dalam menentu- } \\
\text { kan kondisi akhir, } \\
\text { membuat kesimpu- } \\
\text { lan/ mengecek jawaban }\end{array}$ & $\begin{array}{l}\text { - Reviewing: meminta siswa untuk melihat kembali } \\
\text { apa yang ditanyakan pada soal } \\
\text { - Making connection: menghubungkan apa yang } \\
\text { ditanyakan dengan hasil yang telah diperoleh, } \\
\text { 'perhatikan pada tahap akhir petunjuknya. Pada }\end{array}$ \\
\hline
\end{tabular}


tahap ini kamu disuruh menentukan jawaban serta memeriksanya. Sehingga kamu harus memeriksa dahulu jawaban kamu. Sekarang, bagaimana kamu memeriksanya?'

\section{Diagnosis kesulitan Kelompok 3 (K3) dan Upaya Membantunya}

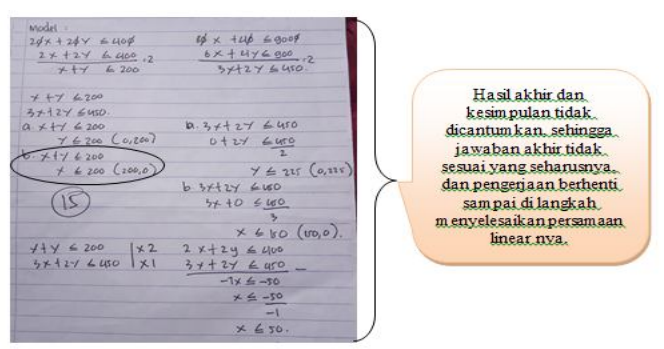

Gambar 3. Jawaban Siswa K3

Hasil akhir pekerjaan K3 benar, namun K3 tidak menyelesaikan soal dengan sempurna. K3 tidak mencantumkan kondisi awal. Untuk membantu kesulitan tersebut, K3 diarahkan agar dapat mengerjakan sesuai panduan. K3 menyatakan ada langkah-langkah pengerjaan soal cerita, tetapi tidak ditulis karena membutuhkan waktu yang cukup lama. K3 lebih berfokus pada proses perhitungan yang juga membutuhkan waktu cukup lama.

\section{Pemberian Scaffolding untuk Mengatasi Kesulitan K3 saat Penyelesaian Soal Materi Program Linier}

Berikut disajikan deskripsi pemberian scaffolding pada K3.

Tabel 3. Identifikasi Jenis Kesulitan Siswa serta Pemberian Scaffolding untuk K3

\begin{tabular}{|c|c|c|}
\hline Jenis kesulitan & $\begin{array}{c}\text { Kesalahan yang } \\
\text { terjadi }\end{array}$ & Bentuk Scaffolding yang Diberikan \\
\hline $\begin{array}{l}\text { Menentukan kondisi } \\
\text { awal }\end{array}$ & $\begin{array}{l}\text { i Tidak menulis kondi- } \\
\text { si awal (yang diketahui } \\
\text { dan ditanyakan) }\end{array}$ & 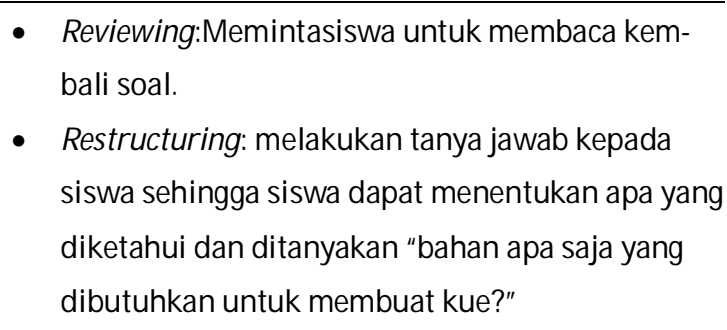 \\
\hline $\begin{array}{l}\text { Menyelesaikan sis- } \\
\text { tem persamaan linier }\end{array}$ & $\begin{array}{l}\text { Kesulitan dalam me- } \\
\text { nyelesaikan sistem } \\
\text { persamaan linier (me- } \\
\text { nemukan nilai y dan } \\
\text { kesulitan dalam mela- }\end{array}$ & $\begin{array}{l}\text { - Restructuring bersamaan dengan explaining : } \\
\text { dengan melakukan tanya jawab serta memberi- } \\
\text { kan contoh. } \\
\text { - } \text { Reviewing: yaitu dengan meminta untuk meli- } \\
\text { hat kembali proses substitusi maupun eliminasi }\end{array}$ \\
\hline
\end{tabular}




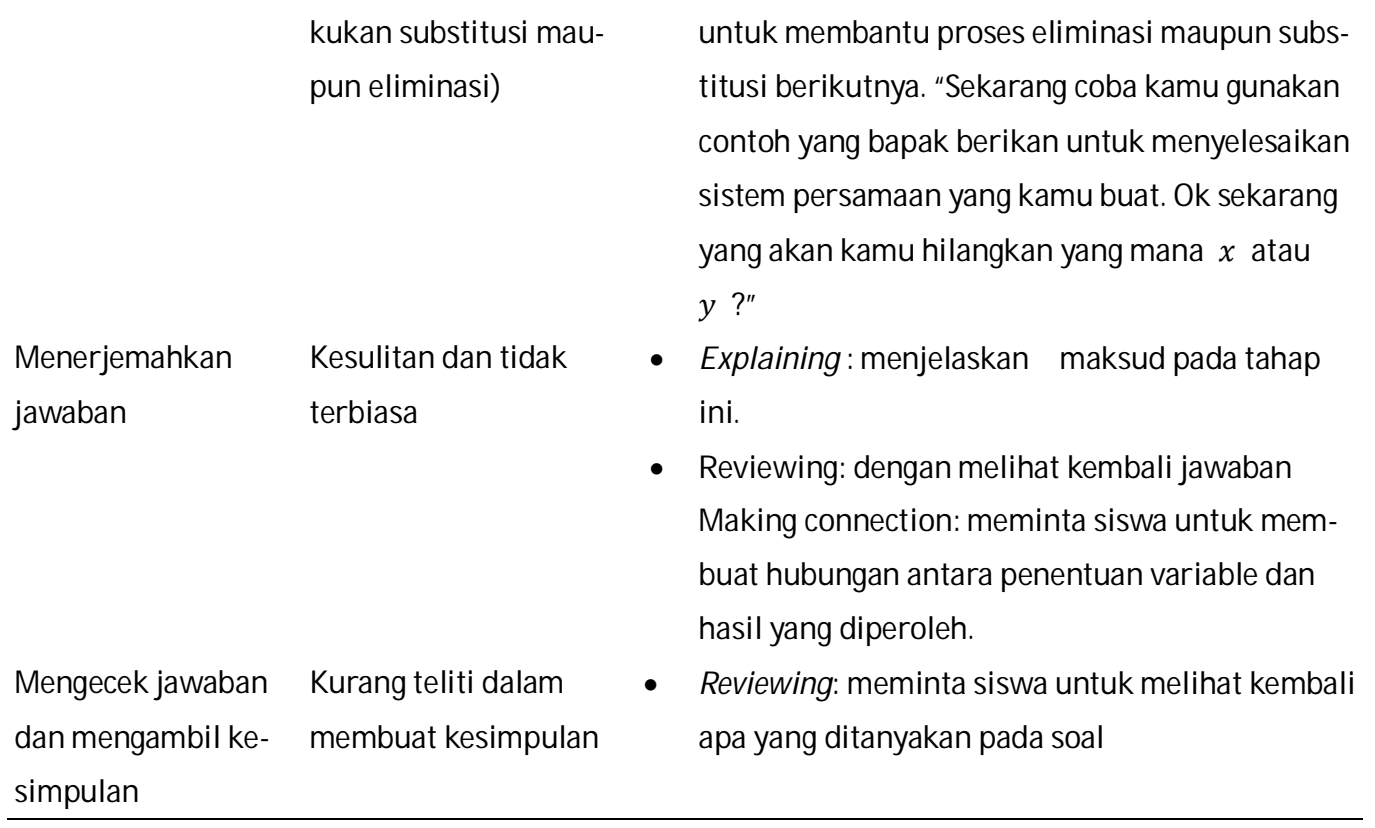

Siswa mengalami kesulitan pada penentuan kondisi awal. Hal ini diketahui dari ketiga kelompok yang menuliskan kondisi awal. Kesulitan tersebut lebih pada anggapan bahwa tahap ini dianggap tidak begitu penting. Siswa terbiasa dengan penggunaan variabel $x$ dan $y$. Coburn (Suwanti, 2016) menjelaskan bahwa langkah pertama penyelesaian masalah program linier adalah menentukan variabel. Siswa tidak memahami masalah serta tidak mampu menggali informasi yang terdapat pada soal untuk diajadikan variabel yang benar. Sujiati (Suwanti, 2016) berpendapat bahwa pemahaman masalah adalah komponen yang sangat penting disaat siswa menyelesaikan masalah, jika siswa mengalami kesulitan dalam hal ini akan membuat siswa tidak dapat melanjutkan penyelesaian masalah.

Penentuan sistem persamaan dapat dikatakan sebagai tahap yang tidak begitu sulit. Tetapi masih terdapat kelompok yang mengalami kesulitan pada tahap ini sehingga menimbulkan kesalahan pada pekerjaannya. Pemberian scaffolding untuk penentuan sistem persamaan ini dilakukan berdasarkan tahapan scaffolding Anghileri level 2, yaitu reviewing dan explaining. Untuk siswa dengan kemampuan matematika tinggi, yaitu K1 dan K2, scaffolding yang diberikan hanya reviewing saja (Santoso et al., 2013). Begitu juga dengan K3 scaffolding untuk tahap ini hanya review jawabannya. Tidak beda jauh dengan K1 dan K2, pemberian scaffolding untuk K3 juga dengan reviewing, tetapi dilakukan juga explaining.

Tahap menyelesaikan sistem persamaan merupakan tahapan inti dari soal 
program linear pada umumnya. Pada tahap penyelesaian masalah ketiga kelompok menggunakan metode gabungan. Metode gabungan lebih banyak dipilih karena metode ini dianggap lebih mudah dan cepat. Tahap menerjemahkan jawaban tidak dilakukan oleh siswa karena tahap ini dirasa masih asing. Hal ini terjadi karena siswa merasa hasil jawaban pada penyelesaian masalah merupakan jawaban yang diinginkan.

Pada tahap pengecekan jawaban seharusnya dilakukan pengecekan ulang jawaban serta penarikn kesimpulan. Pengecekan ulang jawaban dilakukan dengan meminta siswa menggunakan hasil pada tahap penyelesaian kemudian disubstitusikan ke salah satu persamaan yang telah dibuat sebelumnya. Setelah diperoleh hasil yang sesuai, siswa membuat kesimpulan akhir. Tahap pengecekan jawaban merupakan bagian dari proses pemecahan masalah. Hal ini sesuai dengan pendapat Krulik dan Rudnick (Cahyani \& Setyawati, 2016) tentang lima tahap dalam pemecahan masalah yaitu: (1) membaca/ read; (2) mengeksplorasi/ explore; (3) memilih suatu strategi/ select a strategy; (4) menyelesaikan masalah/solve the problem; (5) meninjau kembali dan mendiskusikan/ review and extend. Berdasarkan hasil penelitian seharusnya proses pengecekan dilakukan sebelum menerjemahkan jawaban.

Kesalahan yang dilakukan oleh siswa dapat diperbaiki dengan berbagai bantuan, salah satunya yaitu scaffolding. Sunaryo \& Fatimah (Supiarmo, Mardhiyatirrahmah, \& Turmudi, 2021) menyebutkan bahwa scaffolding yang diberikan kepada siswa dapat membantu untuk mengembangkan keterampilan berpikir dengan baik saat melakukan pemecahan masalah matematika. Adapun kesulitan yang dialami siswa saat menyelesaikan soal program linier yaitu: (1) menentukan kondisi awal; (2) menentukan sistem persamaan linier; (3) proses penyelesaian sistem persamaan linier; (4) proses penerjemahan jawaban; serta (5) pengecekan jawaban. Hal ini sesuai dengan penelitian Mustaqim (2013) yang menunjukkan hasil kesulitan siswa dalam mengerjakan soal program linier diantaranya memahami masalah dan melakukan transfer informasi menjadi variabel, menentukan variabel, menentukan koefisien, menentukan tanda pertidaksamaan, memahami domain, menuliskan bentuk fungsi tujuan, menentukan koefisien, menggambar garis, menentukan daerah penyelesaian pertidaksamaan, dan daerah penyelesaian sistem pertidaksamaan, memahami titik uji, menentukan titik potong dan menarik kesimpulan. 


\section{Kesimpulan}

Berdasarkan hasil dan pembahasan yang telah dilakukan dapat disimpulkan bahwa terdapat lima kesulitan yang dialami siswa dalam menyelesaikan soal cerita materi Program Linear. Kesulitan pertama ditemui dalam proses menentukan kondisi awal (apa yang diketahui, ditanya, serta menentukan variabel). Kesulitan ini dialami semua subjek penelitian. Bentuk scaffolding yang diberikan pada tahap ini mengacu pada tahapan scaffolding level 2, yaitu explaining, reviewing, dan restructuring. Kesulitan kedua ditemui dalam proses menentukan sistem persamaan linear. Pemberian scaffolding mengacu pada tahapan scaffolding level 2 (reviewing dan explaining) serta level 3 (making connection). Kesulitan ketiga ditemui dalam proses menyelesaikan sistem persamaan linear. Scaffolding yang diberikan adalah tahapan scaffolding level 2 yaitu explaining, reviewing, dan restructuring. Kesulitan keempat ditemui dalam proses menerjemahkan jawaban. Untuk tahap ini scaffolding yang diberikan adalah level 2 (explaining dan reviewing) serta level 3 (making connection). Sedangkan kesulitan kelima terjadi pada proses ,engecek jawaban. Untuk itu dilakukan pemberian scaffolding level 2 (reviewing) dan level 3 ( making connection).

\section{Daftar Pustaka}

Amalia, R., \& Putra, E. D. (2019). Refleksi Pembelajaran: Modifikasi Problem Based Learning untuk Mendeskripsikan Kemampuan Berpikir Kritis Siswa. Jurnal Emasains, 8(1), 1-7. Retrieved from https:/ ojs.mahadewa.ac.id/ index.php/ emasains/ article/ view/ 264

Cahyani, H., \& Setyawati, R. W. (2016). Pentingnya Peningkatan Kemampuan Pemecahan Masalah Melalui PBL untuk Mempersiapkan Generasi Unggul Menghadapi MEA. PRISMA, Prosiding Seminar Nasional Matematika, 151-160. Retrieved from https:/ / journal.unnes.ac.id/ sju/ index.php/ prisma/ article/ view/ 21635/ 10234 Haeruman, L. D., Rahayu, W., \& Ambarwati, L. (2017). Pengaruh Model Discovery Learning Terhadap Peningkatan Kemampuan Berpikir Kritis Matematis Dan Self-Confidence Ditinjau Dari Kemampuan Awal Matematis Siswa SMA Di Bogor Timur. Jurnal Penelitian Dan Pembelajaran Matematika, 10(2), 157-168. https:/ doi.org/ 10.30870/jppm.v10i2.2040 
In'am, Akhsanul \& Hajar, S. (2017). Learning Geometry through Discovery Learning Using a Scientific Approach. International Journal of Instruction, 10(1), 55-70. Retrieved from https:/ / files.eric.ed.gov/ fulltext/ EJ1125137.pdf

Jatisunda, M. G., Suciawati, V., \& Nahdi, D. S. (2020). Discovery Learning with Scaffolding to Promote Mathematical Creative Thinking Ability and Self-Efficacy. Al-Jabar: Jurnal Pendidikan Matematika, 11(2), 351-370. https:/ / doi.org/ 10.24042/ ajpm.v11i2.6903

Kamarullah, K. (2017). Pendidikan Matematika di Sekolah Kita. Al Khawarizmi: Jurnal Pendidikan Dan Pembelajaran Matematika, 1(1), 21. https:// doi.org/ 10.22373/jppm.v1i1.1729

Khatimah, K., Sa'dijah, C., \& Susanto, H. (2017). Pemberian Scaffolding untuk Mengatasi Hambatan Berpikir Siswa dalam Memecahkan Masalah Aljabar. Jurnal Kajian Pembelajaran Matematika, 1(April), 52-63. Retrieved from http:/ / journal2.um.ac.id/ index.php/ jkpm/ article/ view/ 782/ 482

Larasati, Y., \& Mampouw, H. L. (2018). Pemberian scaffolding untuk menyelesaikan soal cerita materi perbandingan senilai dan berbalik nilai. Math Didactic: Jurnal Pendidikan Matematika, 4(1), 47-56. https:/ / doi.org/ 10.33654/ math.v4i1.85

Mustaqim. (2013). Berdasarkan Diagnosis Kesulitan Siswa dalam Menyelesaikan Masalah Program Linear dengan Menggunakan. Pendidikan Matematika-Universitas Negeri Malang, 1, 72-78. Retrieved from https:/ / media.neliti.com/ media/ publications/ 123206-ID-none.pdf

Putra, E. D., \& Amalia, R. (2020). Upaya Meningkatkan Kemampuan Berpikir Kritis Mahasiswa Melalui Pembelajaran Discovery Learning Berbasis Assessment Learning. Journal of Education and Learning Mathematics Research (JELMaR), 1(1), 57-64. https:/ / doi.org/ 10.37303/ jelmar.v1i1.17

Ramdhani, M. R., Usodo, B., \& Subanti, S. (2017). Discovery Learning with Scientific Approach on Geometry. Journal of Physics: Conference Series, 895(1). https:/ / doi.org/ 10.1088/ 1742-6596/ 895/ 1/ 012033

Santoso, B., Nusantara, T., \& Subanji. (2013). Diagnosis Kesulitan Siswa dalam Persamaan Linear Dua Variabel Serta Upaya Mengatasinya Menggunakan Scaffolding. KNPM V, Himpunan Matematika Indonesia, (Juni), 491-503. Retrieved from https:/ / adoc.pub/ diagnosis-kesulitan-siswa-dalam-menyelesaikan-soal-ceritama.html 
Sari, N. I. P., Subanji, \& Hidayanto, E. (2016). Diagnosis Kesulitan Penalaran Matematis Siswa dalam Menyelesaikan Masalah Pola Bilangan dan Pemberian Scaffolding. Konferensi Nasional Penelitian Matematika Dan Pembelajarannya (KNPMP I) Universitas Muhammadiyah Surakarta, (ISSN : 2502-6526), 385-394. Retrieved from https:// publikasiilmiah.ums.ac.id/ bitstream/ handle/ 11617/ 6979/41_122_Mak alah Rev Nur Indha Permata Sari.pdf?sequence=1 \&isAllowed=y

Simamora, R. E., Saragih, S., \& Hasratuddin, H. (2018). Improving Students' Mathematical Problem Solving Ability and Self-Efficacy through Guided Discovery Learning in Local Culture Context. International Electronic Journal of Mathematics Education, 14(1), 61-72. https:/ / doi.org/ 10.12973/ iejme/ 3966

Supiarmo, M. G., Mardhiyatirrahmah, L., \& Turmudi, T. (2021). Pemberian Scaffolding untuk Memperbaiki Proses Berpikir Komputasional Siswa dalam Memecahkan Masalah Matematika. Jurnal Cendekia: Jurnal Pendidikan Matematika, 5(1), 368-382. https:/ / doi.org/ 10.31004/ cendekia.v5i1.516

Suwanti, R. (2016). Proses Scaffolding Berdasarkan Diagnosis Kesulitasn Siswa Dalam Menyelesaikan Masalah. Konferensi Nasional Penelitian Matematika Dan Pembelajarannya (KNPMP I) 440 Universitas Muhammadiyah Surakarta, (KNPMP I 12 Maret 2016), 440-448. Retrieved from https:// publikasiilmiah.ums.ac.id/ bitstream/ handle/ 11617/6985/47_129_Mak alah Rev Ria Suwanti.pdf?sequence=1\&isAllowed=y

Yaumi, M. (2018). Media dan Teknologi Pembelajaran. (1st ed.; S. Sirate, ed.). Retrieved from https:/ / core.ac.uk/ download/ pdf/ 227425718.pdf

Zaqiyah, K., Lutfiyah, L., \& Sulisawati, D. N. (2020). Pengembangan Modul Berbasis Realistic Mathematics Education untuk Pembelajaran Bangun Ruang Sisi Lengkung. Laplace: Jurnal Pendidikan Matematika, 3(2), 151-162. https:/ / doi.org/ 10.31537/ laplace.v3i2.381 